in a sea-water aquarium containing starved $P$. duplicata. The Polynices readily attacked the coated clams and drilled typical holes without any interference from the wax layers. This established the fact that the drilling process is basically mechanical but did not preclude the auxiliary use of chemical secretions to soften the hard calcareous shell after the wax had been scraped away. A number of clams were then coated with plaster of Paris as a further test. Plaster of Paris is a fine powder which consists of partially dehydrated calcium sulphate. When mixed with an appropriate quantity of water it sets within a few minutes and reaches its full degree of hardness after only a few hours. It is insoluble in dilute acids and organic solvents. The Polynices readily attacked clams coated with Plaster of Paris and drilled typical holes through the coatings without apparent difficulty.

The results of these experiments indicate clearly that the Naticidae drill holes through the shells of their prey by mechanical rasping with the radula, unaided by chemical secretions. The function of the so-called "boring gland" is not apparent, but its structure and location suggest that it may be an adhesive pad that holds the anterior extremity of the proboscis firmly against the shell to facilitate the action of the radula.

\section{REFERENCES}

Ankel, W. E. 1937. Wie bohrt Natica? Biol. Centralbl., 57.

- 1938. Erwerb und Aufnahme der Nahrung bei den Gastropoden. Zool. Anz., Suppl., 11.

Boettger, C. R. 1930. Die Lage der Bohrstelle beim Angriff der Raubschnecken aus der Familie Naticidae. Zeit. wiss. Zool,, 136.

Fischer, P. H. 1922. Sur les Gastropodes perceurs. J. Conchyliol., 67.

Hirsch, G. Chr. 1915. Die Ernahrungsbiologie fleischfressender Gastropoden. Zool. Jahrb., Abt. Allg. Zool., 35.

Jensen, Ad. S. 1951. Do the Naticidae (Gastropoda Prosobranchia) drill by chemical or by mechanical means? Vidensk. Medd, Dansk. naturh. Foren., 113.

Pelseneer, P. 1925. Gastropodes marins carnivores Natica et Purpura. Ann. Soc. Roy. Zool. Belgique, 55.

Schiemenz, P. 1891. Wie bohrt Natica die Muscheln an? Mitt. Zool. St. Neapel., 10.

Thorson, G. 1935. Studies on the egg capsules and development of arctic marine prosobranchs. Medd. om Grønl. 100 (5).

Harry J. Turner, JR.

Woods Hole Oceanographic Institution, Woods Hole, Massachusetts

\title{
A PHYSIOLOGICAL LIGHT TRAP
}

Color responses discovered in the Cladocera (Smith and Baylor, in press) suggest a light trap for their capture. Organisms exposed first to long wave lengths will swim downward upon sudden exposure to short wave lengths.

Although Cladocera are attracted strongly to any weak light, by shining only the long wave lengths (yellow light) out into the water the individuals attracted become properly exposed as they swim in. An arrangement is then made so that, sooner or later after an individual reaches the yellow light, it will swim into short wave lengths (blue light). As it then swims downward it passes through a funnel into a suitable cage.

One version of this principle is shown in Figure 1. It has the advantage of simplicity both in construction and use. The weak light is not a disadvantage; the effect of changing from yellow to blue is greater at low than at high intensities. The colors are controlled by using a Wratten $\mathrm{K} 2$ or F filter (Kodak), lining the inside of the test tube from the point "a" upward, and a small piece of blue cellophane in the bottom below this point.

The levels must be adjusted carefully so that no blue light escapes over the top of the funnel.
The pen-light bulb is so built that is focuses a sharp cone of light downward, ideal in this case for the blue light.

As organisms swim against the test tube, a downcurrent is set up which is surprisingly efficient in carrying individuals down across the color boundary into blue light. Once across the boundary their own responses do the rest.

This particular trap could be improved in at least two ways: (1) if the blue light were a second source, mounted above the yellow light so as to project a cone of blue downward all around the test tube, organisms would not have to drop first in order to be caught; (2) if the yellow light were polarized so that the plane of vibration were horizontal in the rays shining out, the fishing area would be doubled without increasing the light intensity (Baylor and Smith, in press).

Customarily this trap is floated on a lake in the evening and picked up at leisure the following morning. It is specific, not for a taxonomic group, but for a physiological group. If a species is to be caught, it must be attracted to a yellow light and repelled or caused to swim downward upon changing from yellow to blue.

Cladocera caught in several settings include: 


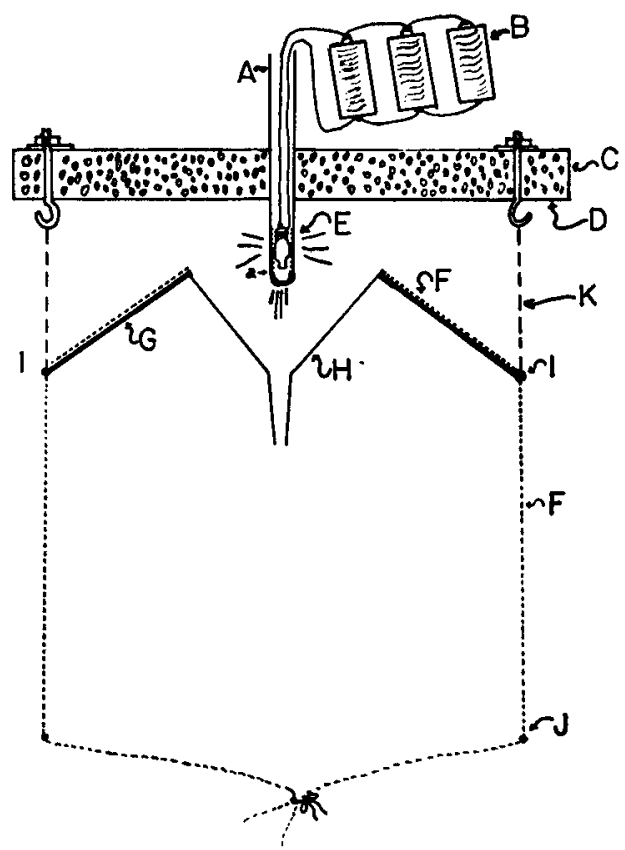

FIG. 1. A physiological light trap for Cladocera and other animals. A, large test tube piercing float; $\mathrm{B}$, three 1.5 volt flashlight batteries in parallel taped around test tube; C, float with four suspension hooks; $D$, reflecting surface; E, 2.2 volt pen-light bulb; F, bolting cloth; $G$, six $1 / 8$-inch rod supports; $H$, ordinary aluminum funnel; $I$, $J$, quarter-inch metal rings; $K$, cylinder of $1 / 4$-inch mesh screen as a fish guard hung on hooks.

Sida crystallina (Müller), Daphnia longispina hyalina (Leydig), Simocephalus vetulus (Müller), Ceriodaphnia reticulata (Jurine), Bos- mina obtusirostris (Sars), Chydorus globosus (Baird), Kurzia latissima (Kurz), and Lepto. dora kindtii (Focke).

Other organisms caught include the phantom larvae of the genus Chaoborus, the swimming larvae of the caddis fly genus Triaenodes, and various water mites.

Single catches often numbered hundreds of thousands of specimens.

The collection of carnivorous forms (Leptodora, Chaoborus, and water mites) has its disadvantages. On one occasion, when the contents were removed from the trap at midnight, several hundred Sida and Simocephalus were seen. By morning all save two were gone, eaten by the two hundred water mites that were also taken.

The basic principle of this trap, that of using one kind of light to attract and so condition an organism that a second kind of light will produce a fateful response, should be of widespread application. A trap which samples efficiently a group of organisms with common behavior pattern should be especially useful in ecological studies. Endless combinations of light responses can be used to create a large variety of traps, and by varying their complexity the traps could be made as specific as desired.

\section{REFERENCES}

Baylor, E. R., and F. E. Smith. In press. The orientation of Cladocera to polarized light. American Naturalist.

Smith, F. E., and E. R. Baylor. In press. Color responses in the Cladocera and their ecological significance. Amer. Nat.

EDWARD R. BAYLOR Frederick E. SMITH

Department of Zoology, UNIVERSITY OF MICHIGAN, Ann Arbor, Michigan

\section{AN INSTRUMENT FOR QUANTITATIVE STUDIES OF PHOTOTAXIS}

The phototactic and geotactic responses of Cladocera have recently been investigated by Baylor and Smith and by Smith and Baylor (both papers accepted for publication in American Naturalist). The data reported were qualitative. Quantitative information on the phototactic behavior of Cladocera can be secured with the photoelectric apparatus described below.

While Daphnia magna (Straus) was the experimental animal used throughout the present studies, the apparatus should work equally well for other swimming organisms which show positive phototaxis.

The apparatus consists of an aquarium containing Cladocera plus the appropriate photo- electric devices for alternately turning off one light source and turning on another.

The experiments were carried out in a small glass aquarium $8 \times 10 \times 12$ inches. The inside of the aquarium was lined with dull surface black plastic to reduce internal reflections. Two Erb and Gray microscope lamps were arranged to give vertical beams of light through the water to the photoelectric cells beneath the aquarium (Fig. 1). Two one-inch round holes with centers eight inches apart were cut in the black plastic lining of the top and bottom to allow the light to pass through.

Vickers Ltd. barrier-layer cells were used for measuring the population density of animals 